\title{
Rediscovery of Crotalaria meeboldii (Fabaceae), a threatened species after more than a century
}

\author{
Daimalu Baro ${ }^{1 *}$, Amal Bawri ${ }^{2}$ \& Sachindra Kumar Borthakur ${ }^{3}$ \\ ${ }^{1}$ Manas Tiger Project, BTC, Govt. of Assam, India. \\ ${ }^{2}$ North Eastern Institute of Folk Medicine (An Autonomous institute under Ministry of AYUSH), Pasighat, \\ Arunachal Pradesh - 791 102, India. \\ ${ }^{3}$ Department of Botany, Gauhati University, Guwahati, Assam - 781 014, India. \\ *E-mail: daimalupbaro@gmail.com
}

\begin{abstract}
Crotalaria meeboldii Dunn, a threatened endemic species confined to northeast India, has been rediscovered from a new locality in the same region after more than a century. Since its first collection in 1912, the species has been known only by its type specimens and assumed to be extinct. A detailed description of the species and photographs are provided here. The inflorescence was originally described as $50 \mathrm{~cm}$ long, but in the present investigation it is found that it is only up to $15 \mathrm{~cm}$ long. The species is assessed here as critically endangered (CR).
\end{abstract}

Keywords: Assam, Conservation, Endemic, IUCN.

\section{Introduction}

Crotalaria L. belonging to the family Fabaceae, comprises of approximately 702 species distributed mainly in tropics, with greatest diversity (c. 540 species) in Africa and Madagascar (Le Roux et al., 2013). Eighty five species are reported from India, distributed mainly in two centres of diversity - the Eastern Himalayas and the Western Ghats. The genus shows high degree of endemism in India with 47\% are endemic to Peninsular India (Ansari, 2008). During a recent floristic survey in Manas National Park, Bhuyapara Range in Assam, the authors came across an interesting specimen of Crotalaria. Detailed study in consultation with relevant literature (Sanjappa, 1991; Ansari, 2008) and comparison with the type, the specimen was

Received: 18.09.2019; Revised \& Accepted: 18.11.2019 Published Online: 31.12.2019 identified as C. meeboldii, a threatened, endemic species of Northeast India. Information from herbarium specimens at major Indian herbaria (ARUN, ASSAM, BSD, BSHC, CAL, DD) and published literature revealed that $C$. meeboldii was earlier known only from its type collection. The species was originally collected by A. Meebold in 1907 from Shibong in Naga Hills of Nagaland. After the type collection, although the region had been explored by many botanists (Kanjilal et al., 1934-40; Jain \& Hajra, 1975; Bora \& Kumar, 2003), no further collection of the species could be made. The present collection is a rediscovery of the species after a lapse of 106 years and also confirms its existence in the natural habitat in the northeastern region. Detailed morphology, photographs, status and relevant notes are provided in this paper.

\section{Materials and Methods}

Fresh materials of C. meeboldii were collected from Manas National Park (BTAD) in Assam in June 2017. Detailed morphological observation was made and herbarium specimens prepared following Jain and Rao (1977). Conservation status of the species was assessed as per IUCN versions 3.1 and 4.0 criteria $B$ (geographical range) and D (population size) (IUCN, 2001; 2012). Based on the recorded geocoordinates of the present locality and the type locality, the Extent of Occurrence (EOO) and Area of Occupancy (AOO) of the population were estimated using the conservation assessment tool extension developed by the Royal 
Botanic Gardens, Kew (Moat, 2007) in Arc View. For AOO, a $2 \times 2 \mathrm{~km}$ grid cell size was used. The preliminary assessments thus generated for EOO and $\mathrm{AOO}$ were then subjected for comparison with the IUCN criteria for assigning the threat status of the species.

\section{Taxonomic treatment}

Crotalaria meeboldii Dunn, Misc. Inform. Kew 1912(7): 340. 1912. Lectotype: INDIA, Shibong, Naga hills, 900 m., 12.1907, A. Meebold 7548 (K000591062 digital image!)

Fig. 1

Perennial suffruticose, erect herbs, c. $1.5 \mathrm{~m}$ tall. Stems terete, branched, hirsute, hairs dense on the younger branches. Leaves simple, alternate; petioles c. $0.1 \mathrm{~cm}$ long; lamina linear to lanceolate, 8.0-8.5 $\times 0.3-0.5 \mathrm{~cm}$, acute or obtuse at base, acute at apex, margins entire and ciliate, revolute, abaxially silky pubescent, adaxially glabrous; stipules linear, c. 0.4 $\mathrm{cm}$ long, deciduous. Racemes terminal, $8-15 \mathrm{~cm}$ long, few to many-flowered or flowers solitary in upper axils; bracts 1, linear-lanceolate, $4-5 \mathrm{~mm}$ long, densely white silky pubescent; pedicels $c .2$ $\mathrm{mm}$ long; bracteoles 2 , linear, inserted on the pedicel, 3-4 mm long, covered with white silky pubescence. Calyx bilabiate, $1-1.2 \mathrm{~cm}$ long with conspicuously long white silky pubescence, lobes linear-lanceolate, parted half of the length, upper lip consisting of two sepals and lower lip of three sepals, c. $8 \mathrm{~mm}$ long, connate at base, acute at apex. Corolla blue to purplish blue, light yellow at base, slightly exserted from the calyx or equal; vexillum obovate-elliptic, 7-8 $\times 4-6 \mathrm{~mm}$; wing petals paired, c. $8 \times 3 \mathrm{~mm}$, multi-veined; keel petals angled. Stamens monadelphous; filaments $1.3-3 \mathrm{~mm}$ long, free; anthers dimorphic, basifixed, shorter, c. 1.3 $\mathrm{mm}$ long, dorsifixed, longer, c. $3 \mathrm{~mm}$ long. Ovary sessile, linear, c. $2.5 \mathrm{~mm}$ long; style c. $4.2 \mathrm{~mm}$ long, sub-geniculate, covered with trichomes; stigma brush type and contracted, c. $0.3 \mathrm{~mm}$ long. Pods brown, oblanceolate, c. $1.2 \times 0.6 \mathrm{~cm}$, with short beak and persistent style. Seeds light brown, $1.5-2.0 \times 0.6-1.0 \mathrm{~mm}$.

Flowering $\&$ fruiting: May-September.
Habitat: In grasslands along with Osbeckia nepalensis Hook.f., Melastoma malabathricum L., Uraria picta (Jacq.) Desv., Leea aequata L., Narenga porphyrocoma (Hance) Bor, Cymbopogon flexuosus (Nees ex Steud.) W.Watson and Themeda arundinacea (Roxb.) A.Camus.

Distribution: Endemic to India.

Specimen examined: Assam, Manas National Park, Bhuyanpara range, $26^{\circ} 47^{\prime} 299^{\prime \prime} \mathrm{N}, 91^{\circ} 09^{\prime} 97^{\prime \prime} \mathrm{E}, 150 \mathrm{~m}$, 10.6.2017, D. Baro 4841 (CAL).

Conservation status: Crotalaria meeboldii is neither listed in the Red Data Book of Indian Plants (Nayar \& Sastry, 1987-90) nor in the IUCN Red List (IUCN, 2019) but mentioned as threatened (Ansari, 2008).

The population of this species has been found surviving at a critical status with only a few individuals ( $<100$ mature individuals) in grassland. Because of the grassland habitat, the site faces several anthropogenic pressures, e.g. grazing and prescribed fire for grassland management. Such human activities may completely wipe out the existing population. The extent of occurrence of the species is only less than $100 \mathrm{~km}^{2}$. In the last three years, we observed a steady decline in the quality and territory size of the habitat. Accordingly the species is evaluated as Critically Endangered, as per IUCN Criteria B1ab(iii) and B2ab(iii) (IUCN 2012).

Notes: In the protologue, the inflorescence is described as up to $50 \mathrm{~cm}$ long. But critical observation of fresh specimens and consultation of image of type specimen revealed that it is only up to $15 \mathrm{~cm}$ long.

\section{Acknowledgements}

We deeply acknowledge the help and support of the Department of Environment and Forest, BTC, Govt. of Assam during field survey and collections. The first author is grateful to the University Grants Commission (UGC) for Rajiv Gandhi National Fellowships (RGNF) for Ph.D. programme. 


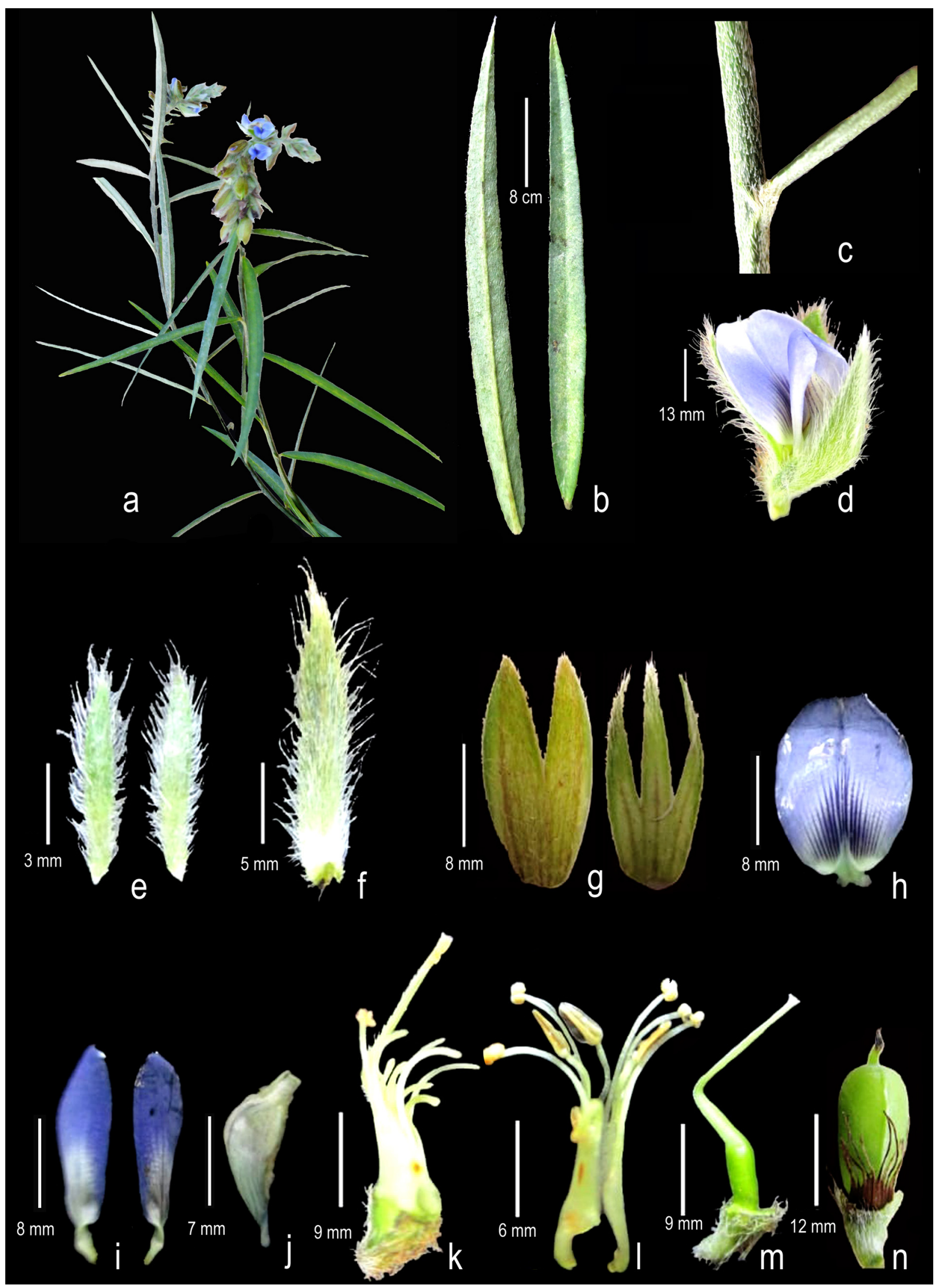

Fig. 1. Crotalaria meeboldii Dunn: a. Habit; b. Leaves; c. A portion of stem; d. Flower; e. Bracteoles; f. Bract; g. Calyx; h. Standard petal; i. Wing petals; j. Keel petal; k. Flowers with petals removed; I. Androecium; m. Pistil; n. Pod. 


\section{Literature Cited}

ANSARI A.A. 2008. Crotalaria L. in India. Bishen Singh Mahendra Pal Singh, Dehradun.

BORA P.J. \& Y. KUMAR 2003. Floristic diversity of Assam: Study of Pabitora Wildlife Sanctuary. Daya Publishing House, New Delhi.

IUCN 2001. IUCN Red List Categories and Criteria: Version 3.1. IUCN Species Survival Commission IUCN, Gland and Cambridge.

IUCN 2012. IUCN Red List Categories and Criteria: Version 3.1. Second edition. Gland, Switzerland and Cambridge.

IUCN 2019. The IUCN Red List of Threatened Species. http:// www.iucnredlist.org (Accessed 25.04.2019).

JAIN S.K. \& P.K. HAJRA 1975. On the botany of Manas Wildlife Sanctuary. Bulletin Botanical Survey of India 17: 75-86.

JAIN S.K. \& R.R. RAO 1977. A hand book of field and herbarium methods. Today and Tomorrow Publishers, New Delhi.

KANJILAL U.N., KANJILAL P.C., DAS A., DE R.N. \& N.L. BOR 1934-40. Flora of Assam. Volume 1-5. Government Press, Shillong.

LE ROUX M.M., BOATWRIGHT J.S. \& B.E. VANWYK 2013. A global infrageneric classification system for the genus Crotalaria (Leguminosae) based on molecular and morphological evidence. Taxon 62: 957-971.

MOAT J. 2007. Conservation assessment tools extension for ArcView 3.x. Version 1.2. GIS Unit, Royal Botanic Gardens, Kew.

NAYAR M.P. \& A.R.K. SASTRY 1987-1990. Red Data Book of Indian Plants, Volume 1-3. Botanical Survey of India, Kolkata.

SANJAPPA M. 1991. Legumes of India. Bishen Singh Mahendra Pal Singh, Dehradun. 